\title{
Els Ausetans a la 2a Guerra Púnica: el paper de les terres del curs mitjà del riu Ter en el conflicte
}

\author{
Montserrat de Rocafiguera i Espona ${ }^{1}$
}

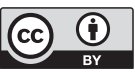

Rebut: $27 / 06 / 2020$

Acceptat: 29/11/2020

\section{Resum}

El paper dels Ausetans a la 2a Guerra Púnica havia estat sempre acceptat i corroborat per les fonts i l'arqueologia. Ara bé, la cita de Livi "Ausetanos prope Hiberum», ha portat a suposar l'existència d'uns altres ausetans a l'Ebre i a fer-los protagonistes dels fets atribuïts pels clàssics. Volem demostrar que les terres del Ter mitjà van ser importants en el conflicte i en les revoltes posteriors, i que és aquest el territori ausetà a què les fonts fan referència, tal com demostren els esdeveniments històrics posteriors que culminen amb la fundació d'Auso.

Paraules clau: Ausetans; Segona Guerra Púnica; revoltes ibèriques; territorialitat; Osona

Abstract. Ausetani in 2nd Punic War: The role of the lands of the middle course of the river Ter in the conflict

The role of Ausetani in the 2 nd Punic War had been traditionally accepted and verified by classical texts and archaeology. Nevertheless, the Livy's quote "Ausetanos prope Hiberum" has led some researchers to assume there were other Ausetani around the river Ebro and to make them the actors of the very important facts that occurred in this time in the north-east of Iberia. We aim to demonstrate that the lands of the middle Ter area were important during the 2nd Punic war and in the Iberian revolts that succeeded to, and that this is the territory which the sources refer, as evidenced by later events that culminated with the foundation of Auso.

Keywords: Ausetani; Second Punic War II; Iberian riots; territoriality; Osona

Rocafiguera i Espona, Montserrat de. «Els Ausetans a la 2a Guerra Púnica: el paper de les terres del curs mitjà del riu Ter en el conflicte». Treballs d'Arqueologia, 2020, núm. 24, p. 85-106. DOI: $10.5565 / \mathrm{rev} / \mathrm{tda} .119$

1. Fundació L'Esquerda. Àrea de recerca. Amb la col-laboració de Imma Ollich, David Serrat, Albert Pratdesaba, Àngels Pujol, Esther Travé, Maria Ocańa. montserratrocafiguera@gmail.com 


\section{Introducció}

Com assenyalen les fonts clàssiques, el poble ausetà té un paper en els conflictes bèl.lics que van tenir lloc al nord-est peninsular durant la segona Guerra Púnica i en les revoltes indígenes posteriors. L'esment sovintejat d'aquest nom en els diferents episodis del conflicte ha fet que d'aquest poble se'n parlés molt, sovint sense tenir en compte el registre arqueològic corresponent. Tradicionalment, aquests ausetans van ser identificats amb el territori d'Osona, on la toponímia de la comarca i de la seva capital, Vic, que s'assimilava a l'Ausa ibèrica, semblaven fer indiscutible aquest fet.

Tanmateix, un estudi dels textos clàssics realitzat l'any 1988 per Pierre Jacob va plantejar la hipòtesi que caldria ubicar els ausetans en un altre punt de la geografia, prop de l'Ebre, proposant l'existència d'un doblet en la toponímia, és a dir, l'existència de dos pobles ausetans, i fent protagonistes dels fets que es narren a les fonts clàssiques, en el context de les Guerres Púniques, precisament els que s'ubicaven prop de l'Ebre (Jacob, 1988).

Aquesta hipòtesi, sorprenentment, ha estat molt poc analitzada des de tots els punts de vista, i, en canvi, ha estat profusament seguida i ha estat presa com a punt de partida inalterable per construir un discurs sobre la dinàmica dels diferents pobles ibèrics en el conflicte, oblidant totalment el poble ausetà clàssic de l'interior de Catalunya.

En el nostre entendre, aquest canvi de paradigma no ha comptat mai amb la base crítica corresponent, de manera que, si bé ha mostrat que és possible l'existència d'un poble ausetà, ausità o osità prop de l'Ebre, no s'ha fet cap pas per negar la hipòtesi contrària, és a dir, no s'ha de- mostrat que els fets que les fonts descriuen no poguessin haver ocorregut en el territori ausetà clàssic.

Així doncs, la qüestió a què volem donar resposta en aquest article no és si van existir o no uns "ausetans» a l'Ebre, sinó si els ausetans «clàssics» entorn del riu Ter tenen entitat suficient per haver estat protagonistes dels fets que se'ls atribueix a les fonts clàssiques, atenent a la seva estructura territorial durant el període ibèric ple, als canvis que es produeixen durant els episodis bèl.lics, i a la seva evolució posterior durant els primers temps de la romanització. Cal tenir en compte, i això és indiscutible, que l'evolució toponímica (Ausetans, Ausa-Auso, AusonaOsona), que ha perviscut fins avui dia en el mateix indret no ens permet negligir el pes específic d'aquests ausetans.

Per analitzar aquesta qüestió, intentarem entendre en primer lloc els motius de «l'oblit» dels ausetans clàssics en la historiografia, que ha portat a acceptar facilment i de manera poc crítica una altra hipòtesi; en segon lloc intentarem analitzar les bases empíriques on s'assenta la hipòtesi sobre els ausetans de l'Ebre, i en tercer lloc farem una anàlisi del territori ausetà des de l'arqueologia, que permeti fer una nova lectura d'aquest període tan important i que tant d'interès suscita.

\section{El territori ausetà i la historiografia}

A partir dels treballs de Bosch i Gimpera, i dels seus deixebles, que dibuixen un primer panorama global del món ibèric a Catalunya en el qual els Ausetans tenen el seu protagonisme (Bosch i Gimpera, 1932), l'estat de la recerca d'època ibèrica a Osona es veu afectat pel doble enfocament que s'aplica la recerca catalana en els 

del riu Ter en el conflicte

àmbits de la prehistòria i la protohistòria a partir dels primers decennis del segle Xx. D'una banda, la tradició "acadèmica», portada a terme gairebé sempre des de Barcelona, s'ocupava de la sistematització i de la síntesi historiogràfica, D'altra banda, la recerca local, fins i tot localista, en mans de les persones coneixedores del territori, gairebé mai no arribava a les instàncies acadèmiques $i$, per tant, no formava part de la visió de la síntesi interpretativa que es trobava a la base dels estudis acadèmics d'aquests períodes antics. ${ }^{2}$ Com que els ausetans apareixien de manera indiscutible les fonts clàssiques, hi eren esmentats, però la manca de coneixement arqueològic de la zona va fer que se'ls considerés en els treballs de síntesi, des de Barcelona, com a una part del rerepaís, marginal en el desenvolupament de la cultura, i d'iberització tardana. Així queda reflectit, per exemple, en treballs com Les arrels de Catalunya de M. Tarradell (1962), que defineix per a la cultura ibèrica catalana els grups del Rosselló, l'Empordà-Gironès, el Maresme, grup meridional i grup de Catalunya-Aragó. En altres obres de síntesi posteriors, com per exemple, el Col-loqui sobre els orígens del Món ibèric (1976) o La Baja Época de la Cultura ibérica (1979) els ausetans pràcticament no hi apareixen esmentats.

Aquesta tendència, en el cas de l'arqueologia d'Osona, feta sempre des del territori, es va trencar a la fi dels anys 70 del segle $\mathrm{xx}$, amb l'arribada a la Universitat de professionals formats en el marc de l'arqueologia, que tenien com a referent l'interès per l'arqueologia osonenca. És el cas de la M. Dolors Molas i Imma Ollich a la Universitat de Barcelona, i Miquel Molist a la Universitat Autònoma de Barcelona. Aquests investigadors, ben vinculats a equips de recerca de la capital, van continuar tenint el seu centre de recerca en el territori ausetà, on van donar un impuls inestimable al coneixement de l'arqueologia prehistòrica i protohistòrica, $\mathrm{i}$ també van incorporar la informació procedent de l'arqueologia a la història medieval. Pel que fa al món ibèric i romà, el treball de síntesi fonamental va ser la tesi de llicenciatura de la Dra. Dolors Molas, de l'any 1974-75: La comarca de Osona. Problemática de su iberización y proceso de romanización a través de su carta arqueológica, i la seva posterior posada al dia i publicació: Els Ausetans i la ciutat d'Ausa (Molas, 1982). El simposi d'arqueologia celebrat a Vic l'any 1982 en la commemoració del centenari del Temple Romà, i la publicació de les actes a la revista $A$ usa, volum 10, va suposar un pas endavant en la integració de l'arqueologia osonenca en el conjunt del coneixement científic que es realitzava des dels centres de recerca (Ollich i Rocafiguera, 2002).

Ara bé, en aquest moment on la recerca ibèrica a Osona, també la romana, es comença a desenvolupar, ja eren traçades les línies mestres sobre el coneixement de la cultura ibèrica a Catalunya, fetes d'acord amb les zones molt més ben estudiades, és a dir, des de la costa i a partir de les línies de penetració de l'Ebre i els seus afluents. I les noves dades d'aquest

2. Aquest fenomen que a Osona va ser molt acusat per als períodes de l'antiguitat, no ho va ser tant per a l'Edat Mitjana. Les obres de referència de l'historiador Ramon d'Abadal, que van transcendir l'àmbit local, i la gran tradició del medievalisme centrat entorn de la seu episcopal de Vic i el seu arxiu, amb personatges tan influents com el Dr. Eduard Junyent i el Dr. Antoni Pladevall, van fer que en la síntesi de la història medieval catalana sí que es tingués en compte, almenys pel que fa als documents escrits, el territori osonenc. 

del riu Ter en el conflicte

territori de l'interior s'han anat incorporant al model general, sense modificar-lo. De fet, en una de les darreres revisions sobre l'estat de coneixement del món ibèric a Catalunya, no es fa cap esment dels ausetans (Sanmartí, 2014), cosa que demostra la poca importància que se'ls confereix a l'hora d'entendre globalment el panorama conjunt d'aquesta cultura.

\section{La hipòtesi dels «Ausetans de l'Ebre», una revisió crítica}

És en aquest context interpretatiu que l'any 1988 es publica a la revista Kalathos, del Colegio Universitario de Teruel, l'article "Un doublet dans la géographie livienne de l'Espagne: les Ausetans de l'Ebre». El seu autor, Pierre Jacob (1949), és un professor alsacià que va estudiar a la Universitat d'Estrasburg. La seva vida professional ha estat vinculada a l'Éducation Nationale com a professor d'Histoire-Géographie a diversos instituts de la regió. També ha estat professor de la Université Populaire Européenne, amb una matèria sobre Història d'Estrasburg. Actualment està jubilat. Durant els anys 1982-1985 va formar part de la 73a promoció d'investigadors de la Casa de Velázquez on va participar, entre altres, a les campanyes d'excavacions a Baelo Clandia. La recerca que va realitzar durant aquest període, basada en les fonts clàssiques del període ibèric, va ser la base de la seva Thèse d'État en Lettres et Sciences Humaines És en aquest context que cal emmarcar el treball que ara ens ocupa.

En aquest article, l'autor alsacià analitza de nou els textos clàssics que fan referència als ausetans $i$, basant-se en les quatre vegades que Titus Livi relaciona els ausetans amb el riu Ebre $(34,1 ; 34,20$; $34,21 ; 39-56)$, proposa l'existència d'un doblet en la toponímia ausetana, de manera que, segons l'autor, existirien dos pobles ausetans. Els primers, els ausetans clàssics, situats a la zona d'Osona, que haurien perviscut i que serien els únics existents en l'època de l'escriptor, i uns altres, que estarien situats prop del riu Ebre (ausetanos prope Hiberum), que tindrien un nom igual o similar. Jacob proposa i argumenta que serien aquests els protagonistes dels fets ocorreguts durant la Segona Guerra Púnica i les posteriors revoltes ibèriques, de manera que Amusic seria un reietó d'aquesta zona.

Jacob fins i tot proposa una capital per aquests ausetans del sud, Auci (per això parla d'un possible topònim, Ausitans, que hauria confós Livi), que apareix una vegada en l'Anònim de Ravenna (s. vir dC), i que es troba situat en el Conventus cesaraugustà. Ell planteja situar aquesta tribu ibèrica a la riba sud de l'Ebre, al sistema ibèric, entre Contrebia Belaisca i Segeda. Aquest lloc seria, per un procés de sinecisme, ocupat després pels Belitani, que si bé en alguns textos apareixen com a poble lusità, Jacob creu que es tracta d'un error del copista, que hauria confós una alfa amb una lambda, i que el text original d'Artemidor d'Efès, que es coneix a través d'Esteve de Bizanci, deia «Ausitani», en comptes de «Lusitani».

Tots aquests pobles haurien estat molt poc coneguts per Livi, ja que haurien desaparegut al llarg de la segona centúria $\mathrm{aC}$, i per això l'historiador llatí els assimila als "Ausetani», poble ben conegut i que encara perviu, veient-se en l'obligació d'especificar que està parlant, no dels que coneix, sinó dels que es troben «prop de l'Ebre».

Cal dir que aquest text de Pierre Jacob, que és, sens dubte, un treball excellent i molt suggeridor per la hipòtesi que 

del riu Ter en el conflicte

se'n deriva, és un exercici intel-lectual de primer ordre. Ara bé, es basa només en els textos, no té en compte la base arqueològica - segurament ni ho pretén-i parteix del coneixement generalista del moment sobre la cultura ibèrica al nord-oest, en la qual els ausetans "clàssics», com hem explicat abans, hi tenen tan poc de pes específic. Ara bé, aquesta hipòtesi ha estat molt ben acollida per un sector de la comunitat arqueològica, s'ha acceptat de manera directa, i un xic acrítica, i ha servit de base per a la construcció de l'explicació de les dinàmiques poblacionals de la zona del Baix Aragó.

Així doncs, Francisco Burillo fa totalment seva aquesta proposta i l'adapta a l'enorme recerca arqueològica portada a terme pel seu equip des del Colegio Universitario de Teruel. Així, en l'article "Propuesta de una territorialidad étnica para el Bajo Aragón. Los Ausetanos del Ebro u Ositanos», publicada també a la revista Kalathos (Burillo, 2001), l'autor pren com a base l'article de Pierre Jacob, però modifica lleugerament la situació d'aquests nous ausetans, emplaçant-los entre la zona d'Aguas Vivas i el Matarranya. La capital d'aquest poble, que ell anomena Osità, la situa a Osicerda, coneguda per una encunyació monetària tardana, que ell situa al Palao d'Alcanyís (Benavente et al., 2003). Burillo identifica aquest poble amb una etnicitat dife- rent dels seus veïns a partir d'un fòssil director, las «Estelas del Bajo Aragón», unes esteles de pedra amb baixos relleus, on hi apareixen unes representacions de llances. ${ }^{3}$ Aquest poble hauria pactat amb ilergets, sedetans i edetans en el context de la 2a Guerra Púnica i de les revoltes posteriors (Burillo, 2001).

A partir d'aquest treball, la nova distribució del poblament ibèric ha estat acceptada per molts dels investigadors, i, sense aprofundir en la pròpia teoria en si mateixa, ha servit per bastir noves explicacions sobre el desenvolupament de les Guerres Púniques al nord-est peninsular. Els Ositans apareixen sovint en el mapa i en les darreres síntesis i revisions sobre aquest període se'ls dona, val a dir que, sense cap explicació específica, el paper de protagonistes (Sanmartí i Santacana, 2005; Noguera et al., 2013; Santacana i Revilla, 2015).

Des del territori ausetà clàssic, el protagonisme dels ausetans de l'Ebre a la Segona Guerra Púnica ha estat presa amb força escepticisme per part de la majoria dels investigadors. A la guia sobre el Turó del Montgròs (El Brull), Alberto LópezMullor esmenta els Ositans, però es mostra escèptic amb la situació de la capital dels Ausetans prop de l'Ebre, ${ }^{4} \mathrm{i}$, en qualsevol cas, reivindica la relació de la destrucció del Montgròs amb el paper dels «nostres» ausetans a les Guerres Púniques ${ }^{5}$

3. Aquesta associació ha estat posada en qüestió amb posterioritat, perquè d'aquestes esteles se'n troben fora del territori del Baix Aragó. I, curiosament, una d’elles és a Tona, al territori ausetà clàssic (Quesada, 2000; Padrós, 2016).

4. «En tot cas, cal tenir present que, quan els romans assetgen la capital dels ausetans, que Livi situa al costat de l'Ebre, els sorprèn una forta nevada, durant la qual "rares vegades el gruix de la neu fou inferior a quatre peus". Aquestes circumstàncies climatològiques podrien haver-se donat, de manera excepcional, al costat de l'Ebre, però, en tot cas, semblen més pròpies de les terres osonenques» (Lopez Mullor, 2016: 53).

5. «En tot cas, sembla que els "nostres" ausetans, després d'un primer enfrontament amb les tropes d'Anníbal, el 218 aC, van abraçar la causa dels cartaginesos contra els romans, cosa que, al final, va comportar la seva derrota i l'abandó del Montgròs» (ibid.). 

del riu Ter en el conflicte

(Lopez-Mullor, 2016). Aquest plantejament també és compartit des de l'equip de recerca de l'Esquerda. En canvi, Carles Padrós fa un estat de la qüestió on accepta el dualisme Ausetans-Ositans, i el protagonisme d'aquests darrers en les guerres Púniques, sense aportar-hi, però, nous arguments (Padrós, 2010, 2016).

\section{El territori ausetà clàssic: una visió actual des de l'arqueologia}

Durant molt de temps, el coneixement del poblament ausetà s'ha recolzat en l'existència de la literatura clàssica que esmenta aquest poble. Amb aquesta perspectiva i la toponímia, s'ha situat la tribu Ausetana a la comarca d'Osona, i de manera similar s'ha situat la seva capital, Ausa, a l'actual Vic, on l'assentament ibèric s'hauria convertit en la ciutat romana, de la qual el temple és una bona mostra (Junyent, 1976: 19).

Ara bé, els projectes de recerca que es porten a terme en el territori des de fa ja algunes dècades, han permès donar una nova visió del país dels ausetans. Els primers estudis van ser els que es van iniciar al Turó del Montgròs, al Brull, que han culminat en una anàlisi molt exhaustiva de l'evolució de l'estructura defensiva, i en una restauració de la muralla i del recinte arqueològic que en fan un assentament molt espectacular (López Mullor, 2010; López Mullor, 2011). També al Casol de Puigcastellet, a Folgueroles, l'excavació va posar en relleu l'interès d'un jaciment molt similar al del Brull, però d'una sola fase constructiva i dues d'ocupació, data- bles al tercer quart del segle III aC (Molas, 1976; Molas et al., 1988); la descoberta l'any 1981 del poblat ibèric de l'Esquerda (Les Masies de Roda) ha vingut seguida d'un conjunt de troballes que permeten parlar no sols d'una estructura defensiva, sinó també d'una planificació urbanística, amb zones diferenciades, barris artesanals, infraestructura hidràulica, un possible santuari urbà i diferents elements, com la inscripció ibèrica de les Graus, que fan pensar en un conjunt que depassa en molt la simple funció defensiva (Rocafiguera, 2019; Rocafiguera, 2020).

A aquests tres projectes encetats a la dècada dels 90, cal afegir-hi els treballs que es porten a terme a Santa Maria de Besora, on, en el context del projecte de restauració del castell medieval i de l'església, s'han trobat indicis de la presència d'un assentament ibèric anterior (Busquets et al., 2017); també s'han reprès les tasques al $\mathrm{Pla}$ del Castell (Tavertet), on s'estudia l'evolució del territori des l'edat del Bronze cap a l'època ibèrica, i on les restes de l'estructura de fortificació presenten informació molt prometedora (Molist et al., 2016).

I encara, són d'especial importància els projectes empresos en el Camp de les Lloses, a Tona (Duran et al., 2016), ${ }^{6}$ des del qual també s'intervé al veí jaciment del Clascar de Malla (Principal et al., 2018), i a Puig Ciutat a Oristà (Padrós et al., 2015), que permeten conèixer l'evolució dels ausetans durant l'època republicana i la seva progressiva integració al món romà fins a la fundació de la ciutat d'Auso, a Vic.

Tot aquest nou coneixement, juntament amb totes les campanyes d'excava-

6. Comunicació de Principal, J. et al., «El Clascar (Malla): primeres evidències arqueològiques d'ocupació ibérica», a III Jornades d'Estudis de la Vall del Ges i Bisaura. Osona al Periode Ibèric. Torelló: Associació d'Estudis Torellonencs. Any, 2018. 


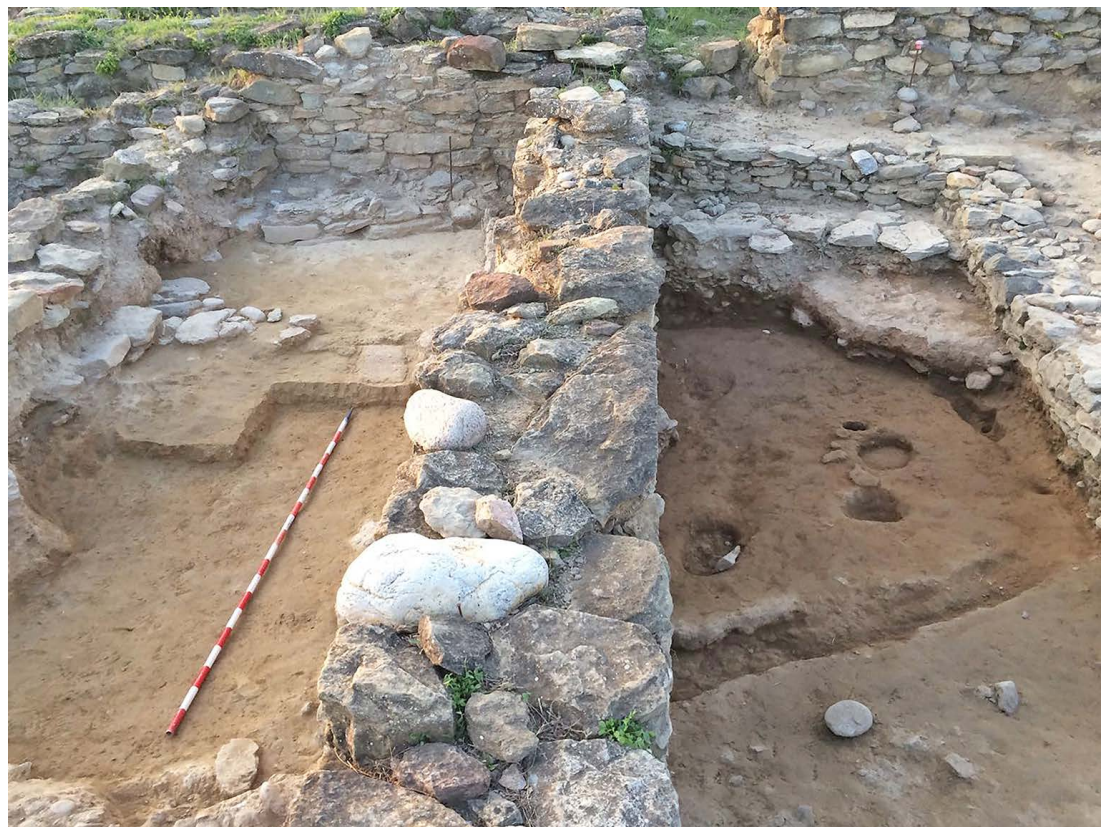

Figura 1. Restes de fons de cabana de la fase inicial de l'Esquerda (imatge: Museu Arqueològic de l'Esquerda).

ció preventiva i d'urgència que s'han portat a terme en els darrers anys, especialment a la ciutat de Vic, i des de l'anàlisi espacial, ha permès donar una nova visió del territori ausetà i reinterpretar el paper, també des de l'arqueologia, que aquesta comunitat va tenir en el desenvolupament del món ibèric del nord-est peninsular i, concretament, en el període de transició del món ibèric cap a la Roma republicana.

Una de les primeres novetats rau en els seus inicis. Les excavacions portades a terme al Turó del Montgròs, al Pla del Castell i a l'Esquerda, permeten situar l'origen del món ibèric ausetà a la fi de l'edat del bronze - inicis de l'edat del ferro, en un moment molt similar al que es produeix en els grans jaciments de la costa. Les troballes realitzades a la Casa 4 de l'Esquerda han permès documentar una seqüència estratigràfica que té com a fase més antiga un fons de cabana de l'edat del Ferro inicial. La segona pertany a un primer ferro ja avançat. Una tercera fase, amb les construccions de pedra, es pot atribuir al període ibèric antic (VI-V aC) Finalment, la gran reforma urbanística que suposa la construcció de l'oppidum fins ara conegut, es pot datar al tombant entre el segle $\mathrm{v}$ i el segle IV aC (Rocafiguera et al., 2012). ${ }^{7}$

7. La datació radiocarbònica practicada a l'embigat de roure de l'àmbit anomenat casa 2, de la fortalesa va proporcionar la cronologia següent: ESQ-96/1 UBAR2325 $\pm 30 \mathrm{BP}$, que permet situar la cronologia entorn de l'any $400 \mathrm{aC}$ (Mestres, 1998; Rocafiguera, 2005). 

del riu Ter en el conflicte

Ara bé, l'etapa on la recerca ha permès conèixer millor el món ibèric ausetà, ha estat el període ibèric ple. En primer lloc, perquè existeixen diversos projectes d'excavació de llarga durada que han permès ampliar la base arqueològica, $i$ en segon lloc, perquè el territori ausetà ha comptat amb diversos treballs de síntesi (Rocafiguera, 1995, 2019; Padrós 2009, 2010) que parteixen de la base de l'arqueologia espacial i que han permès proporcionar una visió de conjunt del país dels ausetans.

A partir d'aquests treballs es pot veure clarament que, almenys des de mitjans del segle $\mathrm{IV} \mathrm{aC}$, el territori ausetà és un territori ben organitzat, que troba els seus límits en els assentaments fortificats en altura que envolten tota la Plana de Vic. Aquests assentaments mantenen una certa equidistància i unes condicions d'intervisibilitat que fan pensar que un dels objectius més importants és el control de l'accés al territori. Aquests assentaments en altura es caracteritzarien per la seva posició estratègica i per les seves potents estructures defensives, que estableixen una xarxa que va més enllà del territori individual de cada fortificació.

Així doncs, en l'estat actual del coneixement, podem distingir la línia de fortificació a l'est del territori ausetà, que de nord a sud, englobaria els jaciments del Castell de Besora (Sta. M. de Besora), Pla del Castell (Tavertet); Savassona (Tavèrnoles), el Puig Castellar Casol de Puigcastellet (Folgueroles) i Turó del Montgròs (el Brull), amb alguns punts intermedis no investigats, però que compten amb material ibèric en superfície i unes característiques físiques similars.

Menys coneguts són els límits per ponent, però també es podrien resseguir: de nord a sud hi hauria una fortificació al Duocastella (Sora), un altre nucli al castell de Voltregà, als peus del qual es va trobar la famosa estela avui exposada al Museu Episcopal de Vic. Més al sud es localitzen materials ibèrics al Castell de Gurb i prop de l'ermita de Sant Sebastià (Santa Eulàlia de Riuprimer), a la zona del Castell de Tona, i a l'indret anomenat Puig Castellar (Balenyà) que se situa sobre els cingles de Centelles.

Tots aquests assentaments en altura sembla que formen una veritable frontera, que ve corroborada pels Black Holes (Groube, 1981), que en el període ibèric ple semblen documentar-se, a manca de prospeccions extensives, a tot el seu entorn. Especialment significatius són el buit de poblament a l'est, a la zona de les Guilleries, fins a arribar a una altra línia de frontera que marcaria l'inici del territori indiget (Nolla i Sanmartí: 1984); i el buit d'ocupació del període ibèric ple de l'àrea del Ripollès, que marcaria el límit entre els territoris ausetà i ceretà. ${ }^{8}$ Sembla que aquest buit d'ocupació no només és atribuïble a la manca de recerca, atès que sí que es troben en aquest territori assentaments de l'Edat del Bronze, que permetrien explicar com l'elaboració d'unes primeres estructures territorials complexes comportarien un replegament de la població rere de les fronteres que provocaria l'aparició d'aquests black holes. Tot i que

8. Aquesta afirmació es basa, a manca de treballs de prospecció sistemàtica, en l'inventari dels jaciments arqueològics de la Generalitat de Catalunya (<www.invarque.cat $>$ ) on no consta per al Ripollès cap assentament del període ibèric ple, mentre que les etapes històriques, anteriors i posteriors, hi són ben representades. 


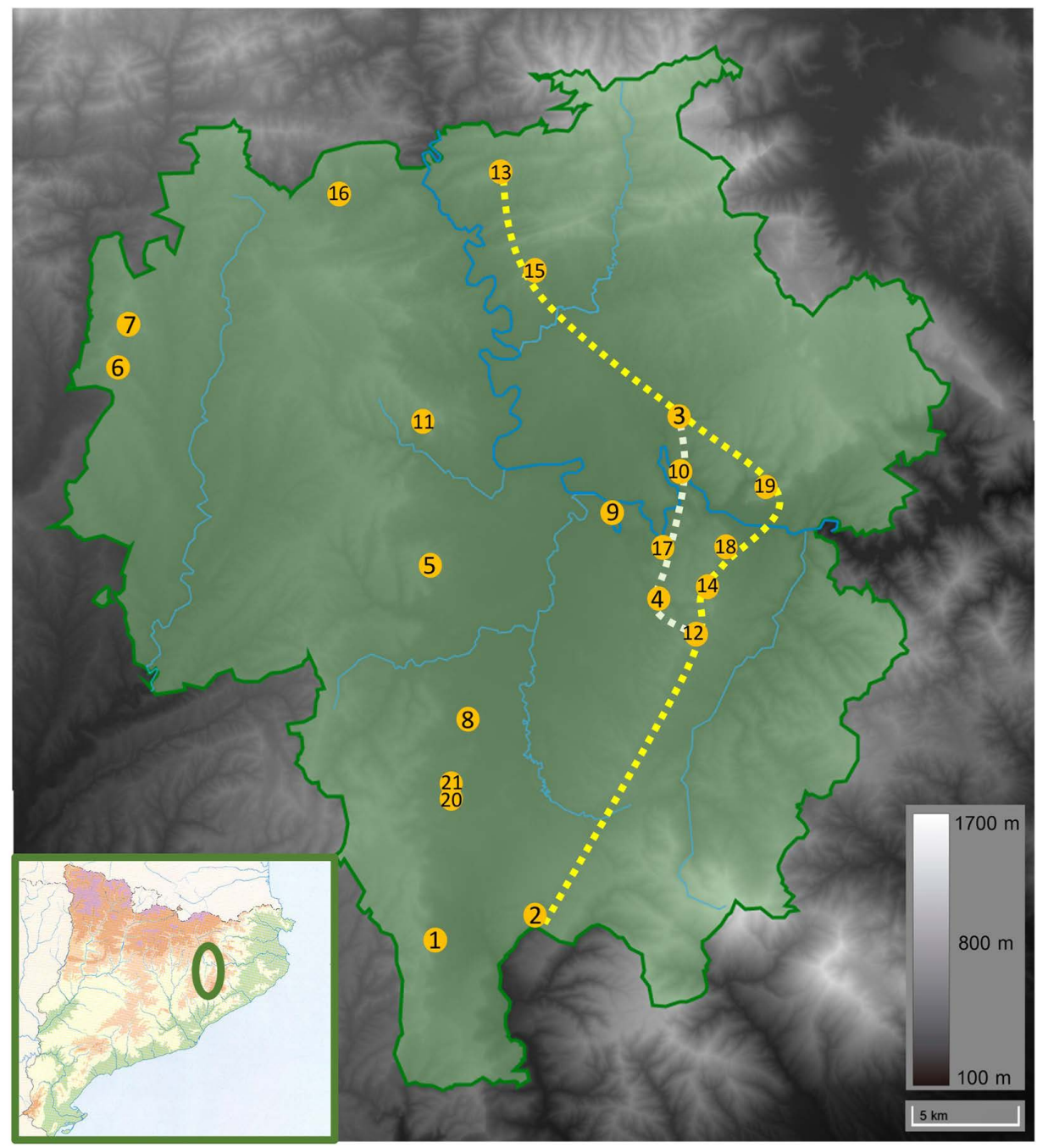

Figura 2. El territori ausetà a la fi del període ibèric ple. El traçat de la frontera oriental. Jaciments identificats: 1. Puig Castellar (Balenyà); 2. Turó del Montgròs (El Brull); 3. Serrat de les Cases (l'Esquirol); 4. El Casol de Puigcastellet (Folgueroles); 5. El Castell de Gurb i Pla de la Noguera (Gurb); 6. Generes (Lluçà); 7. Santa Maria de Lluçà (Lluçà); 8. El Clascar (Malla); 9. L'Esquerda (Les Masies de Roda); 10. Sant Pere de Casserres (Les Masies de Roda); 11. Sant Martí Xic (Les Masies de Voltregà); 12. Sant Llorenç del Munt - la Martellera (Sant Julià de Vilatorta); 13. Castell de Besora (Santa Maria de Besora); 14. El Puig Castellar (Sant Sadurní d'Osormort); 15. Castell de Torelló (Sant Vicenç de Torelló); 16. Duocastella (Sora); 17. Sant Feliuet de Savassona (Tavèrnoles); 18. Puig del Far (Tavèrnoles); 19. El Pla del Castell (Tavertet); 20. El Camp de les Lloses (Tona); 21. El Castell i Contracastell (Tona). 
no són tan clars, també semblen definir-se per la zona del Lluçanès, en límit amb els lacetans i pel sud amb els laietans.

Un jaciment singular en aquest conjunt d'assentaments ausetans és la fortalesa de l'Esquerda. Molt més conegut com a poblat medieval, l'Esquerda s'ha revelat en els darrers anys com a un assentament ibèric d'unes característiques especials: en primer lloc, la seva ubicació, en un dels meandres del Ter, en la transició entre la Plana de Vic i les Guilleries, i la seva superfície, fins a 12 ha envoltades pel riu, li confereixen una situació estratègica particular i una extensió a priori prou gran per pensar amb un assentament central en el territori.

A més, les excavacions portades a terme en els darrers anys han permès identificar-hi una potent fortificació en pedra seca, amb tres torres quadrangulars massisses com a mínim, que protegeix l'assen- tament per l'únic costat accessible, la cara nord. També s'hi reconeixen indicis clars d'urbanisme, especialment amb el traçat d'un carrer longitudinal de nord a sud, que es perpetua fins i tot en l'estructura del futur poblat feudal (Ollich i Rocafiguera, 2019). Així mateix, s'ha documentat al jaciment un sistema d'aprofitament de les aigües pluvials en forma de cisternes, que semblen originàries d'aquest període ibèric i que seran remodelades $\mathrm{i}$ aprofitades durant l'Edat Mitjana (Serrat et al., 2015), i un possible santuari urbà sota el qual després serà l'església romànica de Sant Pere (Ollich et al., 2012). Completen aquest conjunt la presència de diferents àmbits dedicats a la producció artesanal, entre els quals una ferreria i un taller ceràmic. Entorn del jaciment cal esmentar també la inscripció rupestre de les Graus en una balma sobre el riu Ter (Maluquer, 1976).

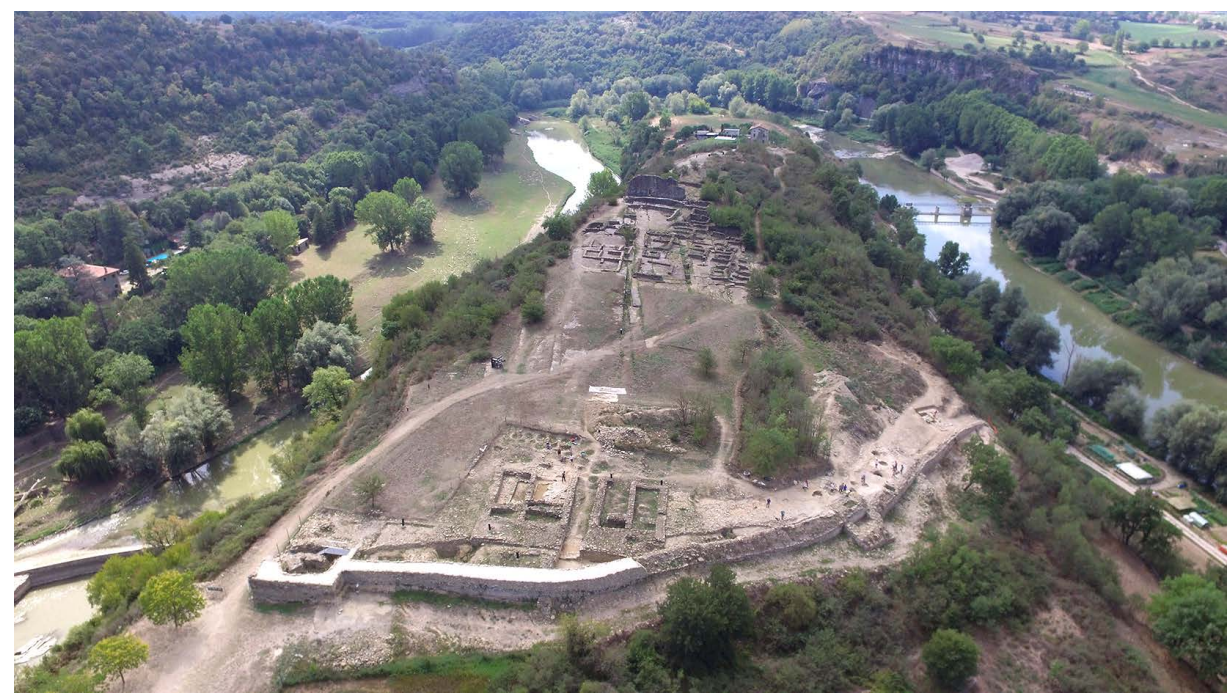

Figura 3. L'Esquerda. Vista aèria general on es pot percebre la seva extensió, la situació geogràfica sobre el Ter, la fortificació i les traces de l'urbanisme (imatge: D. Robles, Museu Arqueològic de l'Esquerda). 
Entre el material arqueològic moble hi destaca la presència de materials d'importació, com la ceràmica àtica, algunes restes d'ambre, i alguns elements de prestigi, com és un penjoll fet amb un ullal d'ós. També, cal esmentar en aquest sentit la presència de fusta d'avet (Abies $a l b a)$. Totes aquestes restes, juntament amb les restes d'armament, entre les quals destaquen dues espases, una d'elles amb beina i morta, restes d'un escut, i diferents puntes de llança i de fletxa, fan pensar que l'assentament constitueix un nucli de comerç a llarga distància, on apareixen a més uns elements de prestigi que permeten suposar-hi una possible «elit», indici de jerarquització social.

No hi ha a l'assentament, fins al moment, restes d'habitatges singulars, però cal pensar que la part més alta de la península, entorn de l'església, el poblat feudal s'ha construït utilitzant la roca mare com a nivell de circulació de les cases, cosa que ha destruït qualsevol estratigrafia anterior. Tanmateix, entre el material remogut de tota la zona apareix

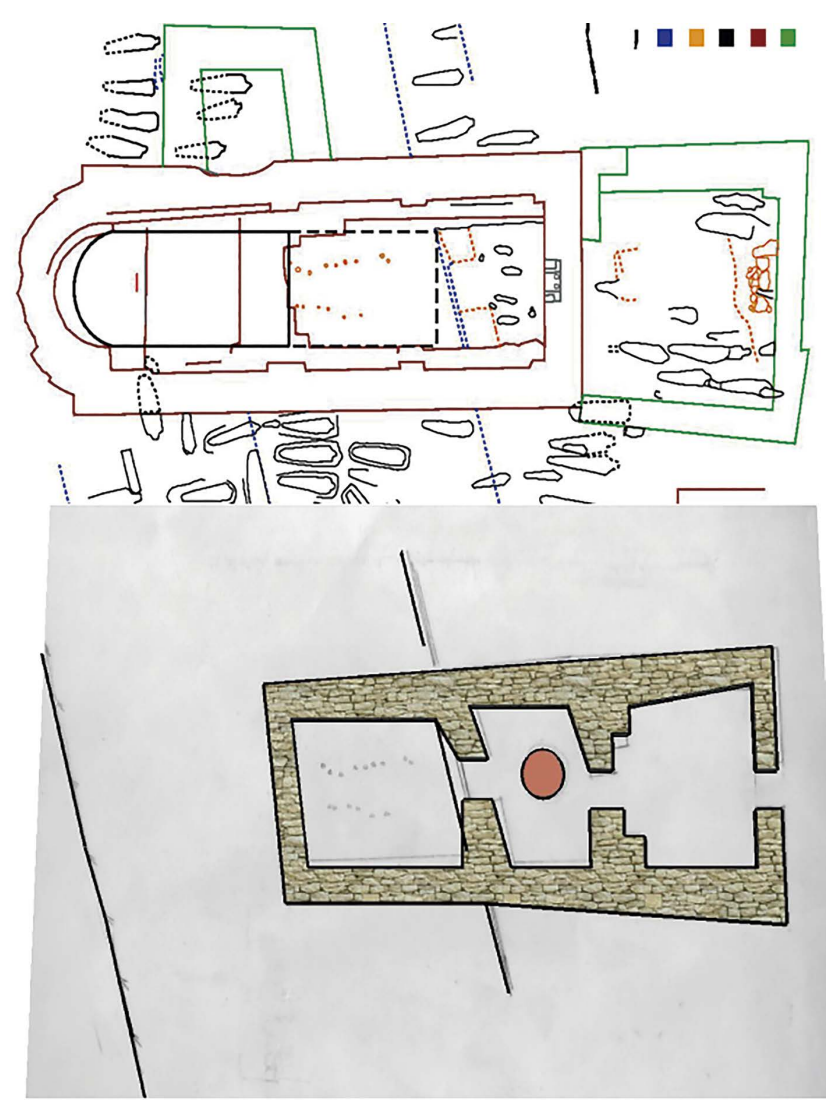

Figura 4. L'Esquerda. Restitució del possible santuari urbà sota l'església romànica de Sant Pere (dibuix: I. Ollich -Museu Arqueològic de l'Esquerda). 
sempre un percentatge significatiu de material d'època ibèrica. Tampoc s'ha localitzat de moment cap resta de necròpolis pertanyent al període ibèric (Rocafiguera, 2020).

Molt menys coneguts són en territori ausetà els assentaments secundaris, cosa que fa difícil fer una jerarquització precisa dels assentaments, tot i que es pot intuir aquesta distribució. D'una banda, cal atribuir aquest fet a la manca de recerca, especialment de prospecció sistemàtica. Per altra banda, els assentaments que presenten evidències o indicis d'ocupació en el període ibèric ple, experimenten un creixement en el període romanorepublicà, $\mathrm{i}$ les restes estructurals visibles pertanyen a aquesta fase. Tot i així, tenim evidències d'assentaments situats en elevacions en el pla, sense signes de fortificació, entre els quals podem citar els assentaments del Clascar de Malla, o el Turó del Castell de Tona (Duran et al., 2016). I, també, assentaments al pla, en petites elevacions prop de corrents d'aigua. Aquest és el cas per exemple del jaciment de Can Caseta, a Manlleu (Huntingford i Molas, 1977), el Puig Guardial, sobre el Ter, les Serrasses, entre el Ter i el Ges a Torelló, i el Camp del Pas sobre el Gurri, prop de Vic (Rocafiguera, 2019).

Així, doncs, segons sembla, el territori ausetà, un territori poblat des de la prehistòria, s'hauria anat organitzant, com les comunitats més ben conegudes dels territoris costaners des de la prehistòria recent, fins a formar un estat arcaic amb unes fronteres ben definides entorn de la Plana de Vic. En l'estat actual del coneixement, hi ha un sol jaciment, l'Esquerda que podria haver adquirit l'entitat de ciutat i una posició central respecte del territori. Podria ser la capital dels ausetans, de la qual parla Titus Livi?

El primer que cal dir és que es pot negar categòricament que l'Ausa ibèrica estigui situada, com la tradició indicava, sota l'Auso romana, a Vic. Els innombra-

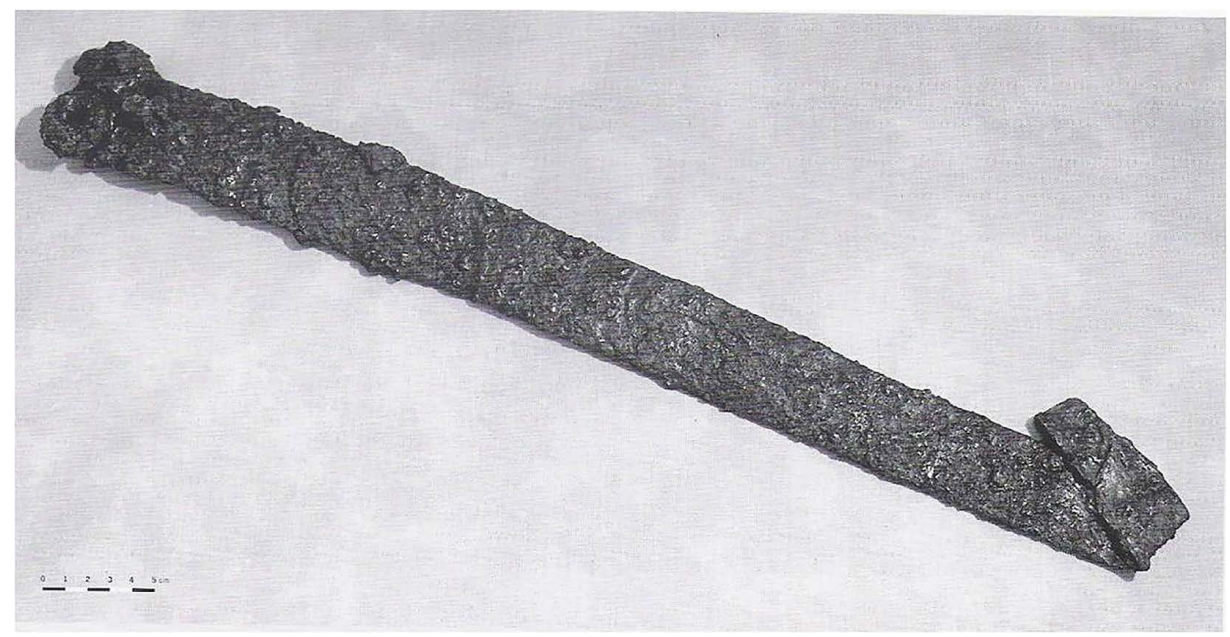

Figura 5. Beina d'espasa morta, localitzada entre els enderrocs del carrer de l'Esquerda (imatge: Museu Arqueològic de l'Esquerda). 
bles treballs d'excavació realitzats en el turó de la ciutat, no han aportat mai cap indici material anterior al segle $\mathrm{I}$ aC. Aquest fet troba també paral.lels en altres pobles de la costa, com Gerunda o Iluro, a les quals també se'ls suposava un origen ibèric, mentre que actualment es consideren ciutats romanes de nova planta. (Nolla, 1988; Martín et al., 2000).

En segon lloc, cal observar, a més de la seva entitat com a ciutat, la continuïtat d'ocupació de l'Esquerda, i el paper central que va tenir en els moments visigòtic i carolingi, (Ollich et al., 2014; Pratdesaba, 2015; Ollich et al., 2016), i el paper que va portar a terme en les lluites feudals que van menar a la seva destrucció l'any 1314, mentre que Vic adquiria el títol de ciutat l'any 1315. El fet que l'assentament de l'Esquerda romangui totalment abandonat durant el període imperial romà, coincident amb la fundació d'una ciutat de nova planta, Auso, que rebrà el nom de l'antiga capital ibèrica, fan pensar en el vincle que podrien haver tingut aquests dos emplaçaments en l'organització del territori del curs mitjà del Ter en els diferents moments de la història.

Des d'aquesta perspectiva, podem rellegir, ara, els textos antics, per analitzar si el paper que les fonts confereixen a aquests ausetans en el conflicte de finals del segle III aC és coherent amb el que mostra l'arqueologia o si realment cal seguir pensant en un altre poble com a protagonista d'aquest conflicte.

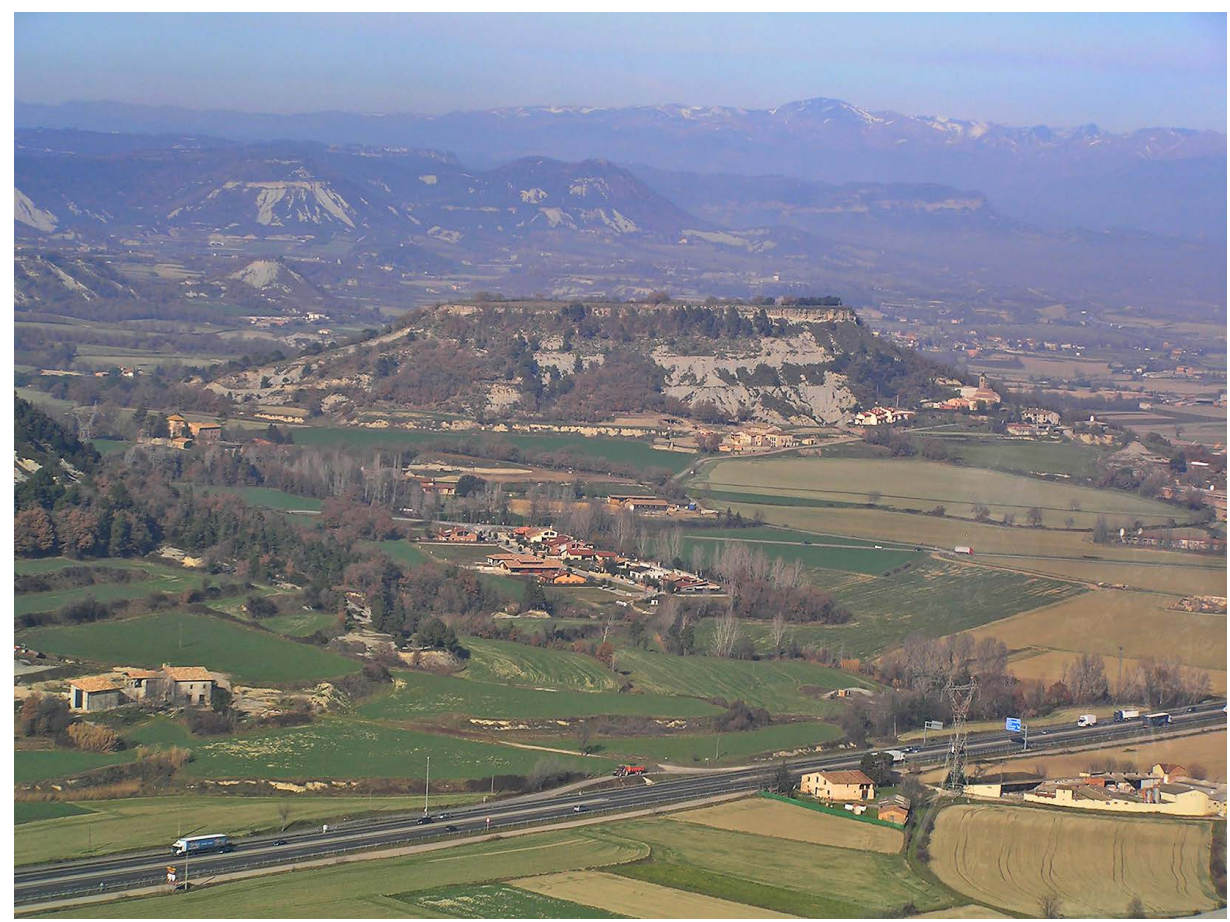

Figura 6. El Clascar de Malla, un possible assentament secundari en el període ibèric ple. 

del riu Ter en el conflicte

\section{La 2a Guerra Púnica i els Ausetans. Una hipòtesi de relat des del territori clàssic}

Que els ausetans van ser importants per als romans per explicar el període històric entre el $218 \mathrm{i}$ el $195 \mathrm{aC}$, queda fora de dubte, pel fet que fins a cinc vegades s'esmenta aquest poble en aquest context, i cinc més en descripcions geogràfiques anteriors o posteriors. ${ }^{9}$ Cal tenir en compte, que, com remarca Cruz Andreotti (2004) el nombre d'esments que les fonts romanes fan dels pobles indígenes no reflecteix tant la importància d'aquests pobles, com l'interès, potser territorial, que aquests tingueren per explicar la història de Roma.

El text de Livi esmenta per primera vegada els ausetans en el pas d'Anníbal des de l'Ebre als Pirineus. Sembla que hi ha unanimitat entre els investigadors en el fet que el cabdill cartaginès va travessar l'Ebre per un lloc allunyat de la desembocadura (Noguera et al., 2013: 61), i que va evitar els passos costaners per fer circular el seu exèrcit. Un dels trajectes més defensats, i que coincidiria amb el relat de Polibi (III, 35,1), és el que remuntaria la vall del Segre, cap a la Cerdanya, i que per la vall de la Tet arribaria fins a la costa (Morera, 2016). Cal no oblidar, però, que existeix un altre pas natural per l'interior, el pas a través de la depressió central, remuntant cap al territori d'Osona, seguint per les valls ceretanes, a través del Ripollès, o prenent la vall de la Tec, a través del Coll d'Ares que porta, vorejant el Canigó per migdia, a la mateixa plana rossellonesa. ${ }^{10}$

Per què el text de Livi esmentaria ilergets, bargusis, ausetans i la Lacetània en aquest pas d'Anníbal, mentre que Polibi esmenta ilergets, bargusis, airenosis i andosins? La hipòtesi de Beltrán Lloris sobre el fet que al territori ausetà $i$ lacetà hi hauria anat a parar l'exèrcit d'Hannó, encarregat de sotmetre els pobles indígenes i de controlar l'interior, ens sembla molt suggeridora (Beltran Lloris, 1984: 166). De totes maneres, el que ens sembla clar és que aquest territori té interès per a la historiografia romana de Livi, perquè podria marcar el límit oriental dels aliats cartaginesos, a la zona de contacte amb les poblacions ja afins al món romà. Cal remarcar que en aquesta cita, Livi no vincula els ausetans a l'Ebre. I aquest fet, que el límit de les zones d'influència entre romans i cartaginesos passa pel territori ausetà, ens sembla que és essencial per entendre el paper els ausetans en aquest període i per què susciten un record tan viu en la historiografia romana.

9. No cal, ens sembla, tornar a repetir l'estudi de tots els textos escrits que fan referència als ausetans, que ja van ser descrits, analitzats exhaustivament i publicats per M. Dolors Molas (1975, 1982), i posteriorment pel propi Pierre Jacob (1988) i per Carles Padrós (2010, 2016). En qualsevol cas, els textos que esmenten específicament els ausetans són, Aviè, Ora Maritima, v. 550 (ausocerets); Livi, Ab Urbe Condita (21:19,6; 21:61; 26:17; 28: 1-3; 34:20-21; 39:56), Apià, Ibèria, 38; Cèsar, Bellum Civile 1,60; Plini, Naturalis Historia III: 2, 21; Ptolomeu: Geografia, 1l, cap. IV, 69. Cal ser conscients que l'obra de Polibi no esmenta els ausetans.

10. Que aquest segon trajecte interior era conegut des de l'antiguitat, ho demostra el relat de Julià de Toledo sobre la revolta del Dux Paul de l'any 672 de la nostra era. Wamba va perseguir els traïdors amb tres exèrcits, i mentre un passava els pirineus per la zona ceretana, un segon atenyia el Pirineu per la ciutat d'Osona i el tercer passava per la ruta marítima (Julià de Toledo Historia Wambae X). Creiem que un gran militar com era Anníbal, que a més, també segons les fonts havia passat l'Ebre dividint l'exèrcit en tres faccions, hauria segurament tingut en compte aquesta segona ruta. 


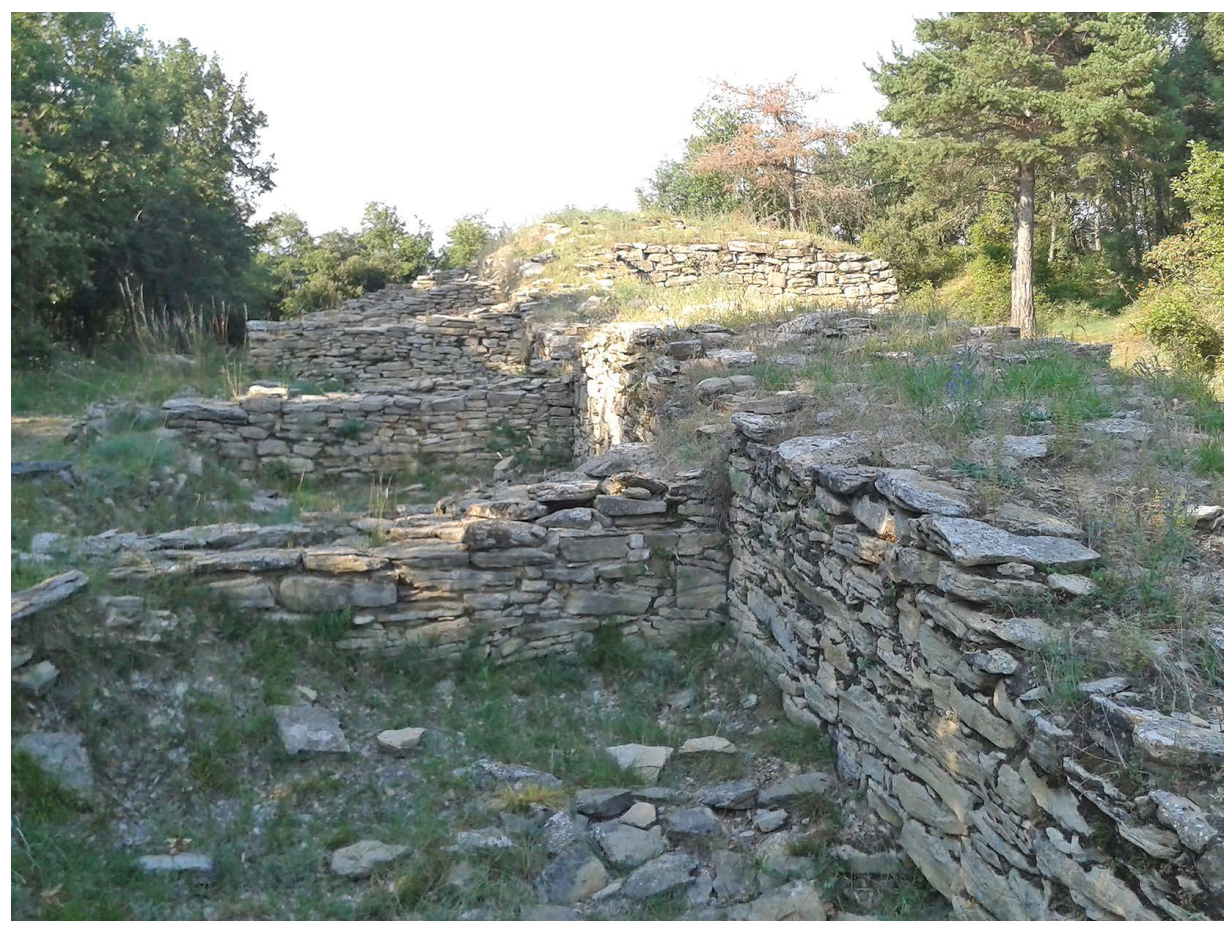

Figura 7. La fortalesa ausetana del Casol de Puigcastellet (Folgueroles).

Que el territori ausetà es prepara per a la guerra també té reflex arqueològic. A la segona meitat del segle III aC s'identifiquen a les fortaleses ausetanes més ben conegudes, al Turó del Montgròs (López Mullor, 2011) i a l'Esquerda (Rocafiguera et al., 2012) refortificacions i remodelacions de l'estructura murària. El cas més paradigmàtic és però el Casol de Puigcastellet, una fortalesa de tipus barrera, construïda entorn d'aquest moment, segurament per controlar una de les vies de penetració des de la costa a través de la vall de Sau. La curta durada d'aquesta fortalesa en aquest període i el seu abandonament posterior és un clar indici del reforçament d'aquesta frontera (Molas et al., 2008).
El desembarcament de Gneu Corneli Escipió a Empúries l'estiu del 218 aC, i l'avanç del seu germà Publi Corneli per mar fins a les boques de l'Ebre, porten la guerra al nord-est de la península durant els sis anys següents. I en aquest context apareixen per primera vegada els ausetans "prope hiberum» (Livi 21:61,8), tot i que l'autor els continua situant prop dels lacetans, com a la cita precedent. Al marge d'aquesta cita concreta, d'altra banda força qüestionada, el que els textos deixen clar és el control del territori de la costa i de les seves tribus per part dels romans, $\mathrm{i}$ en aquest punt hi ha unanimitat entre tots els investigadors. Ara bé, no hem sabut trobar en cap estudi, ni els textos clàssics ho expliciten, quin era el límit inte- 

del riu Ter en el conflicte

rior sota el control dels romans. Nosaltres proposem com a límit de frontera la serralada prelitoral, amb el gran corredor prelitoral. El fet que els textos clàssics divideixin clarament per aquest punt els pobles filoromans dels filocartaginesos ens sembla significatiu. Una altra vegada aquesta línia de frontera coincidiria amb el llevant del territori ausetà. I tindria sentit esmentar-hi el riu —errant-ne el topònim, Hiberus, en comptes de Ter, que fins a la baixa Edat Mitjana tenia el ramal principal de la desembocadura a Empúries.

La 2a Guerra Púnica continua des de l'any 217 fins al $211 \mathrm{aC}$ amb una tònica similar. Els romans intenten portar la guerra cap al sud, seguint la costa, i els textos gairebé no parlen de l'interior. Això ha fet suposar que aquests territoris estaven ja pacificats, però no n'hi ha cap evidència al respecte. Potser simplement la frontera s'havia estabilitzat, i per tant, en no haver-hi grans moviments, les fonts no en fan referència. La batalla d'Hibera, l'any $215 \mathrm{aC}$, citada només una vegada, prop de Tortosa, pot mostrar també que els territoris de l'interior estaven tranquils, cosa que no ha de voler dir que fossin ja pacificats ni sota control dels romans.

La guerra canvia de signe l'any 211 $\mathrm{aC}$, quan els dos germans Escipió són derrotats per l'exèrcit púnic, aparentment al sud d'Hispània, provocant un reequilibri de les forces entre els dos bàndols i fent recular el conflicte una altra vegada al nord de l'Ebre. La historiografia ha inferit que tot el nord era ja sota control romà, cosa que es contradiu amb el fet que, fins i tot en les batalles del sud d'Ibèria els ilergets són documentats com a aliats púnics. Seria possible doncs que, encara en aquest moment, el control efectiu dels romans se cenyís al territori lito- ral? Aquesta explicació seria coherent amb la configuració del territori ausetà clàssic, i amb la importància de fortaleses com la del Turó del Montgròs, que en aquest moment reforça de manera contundent les seves estructures defensives (López Mullor, 2016), per controlar una de les vies d'accés, el Congost, del corredor litoral.

En aquest episodi de la guerra, una altra cita de Titus Livi torna a esmentar els ausetans, quan ens diu que Caius Nero, desembarcat a Tarraco, va ocupar un campament que Asdrúbal tenia a $L a-$ pides Atros (pedres negres), en territori ausetà entre Iliturgi i Mentissa. El topònim Iliturgi que apareix al baix Guadalquivir i el topònim Mentessa també meridional han fet que aquest passatge se situés en territori oretà, al sud de la península. Jacob, al-legant que això no és coherent amb el fet que el desembarcament de Nero es fes a Tarraco, proposa tornar a situar aquest territori prop dels ausetans, de l'Ebre. Ara bé, cal també tenir en compte que la cartografia també recull el microtopònim «Pedres Negres» en territori ausetà clàssic. Es tracta d'una cruïlla de camins, prop de la vila d'Alpens, al Lluçanès. L'espai havia estat ocupat fins a mitjan segle xx per un hostal, del qual s'explicava una antiga llegenda. L'espai fa una altiplanície de $6 \mathrm{Ha}$, amb defenses naturals, que no ha estat mai intervingu$\mathrm{da}$ arqueològicament. En aquest cas Iliturgis i Mentissa, no tenen cap referent clar. Ara bé el radical Tur/Tar/Ter el trobem en molts topònims d'origen preromà a la zona, com en el cas de Torelló, no gaire distant d'aquest punt.

A partir del $210 \mathrm{aC}$ la guerra tomba ja cap al bàndol dels romans, $i$ al nord-est peninsular no es pot parlar ja d'enfrontament armat romanocartaginès. En aques- 

del riu Ter en el conflicte

ta etapa, els pobles indígenes protagonitzen diverses revoltes i els ausetans són un dels pobles sovint revoltats. La primera de les revoltes, la de l'any 206-205 encara segueix la pauta de la guerra, amb l'aixecament dels territoris de l'interior, més filocartaginesos, encapçalada pels ilergets, i és seguida per molts pobles, entre els quals els ausetans. Pierre Jacob afirma que en aquest cas ha de tornar-se a tractar dels ausetans de l'Ebre, cosa que contradiu la seva tesi principal, és a dir, que Livi feia constar l'expressió "prope hiberum» per diferenciar els dos pobles de nom similar, quan en aquest cas el text no ho especifica. Si se sobreentén que els generals romans L. Lèntul i M. Acidinius arriben al territori revoltat partint de l'Ebre, evidentment l'ager ausetanus hauria d'estar situat en aquest lloc; però, i si com en altres ocasions s'hagués partit d'Empúries? En aquest cas, l'exèrcit hauria travessat la depressió central catalana, creuant el territori hostil dels ausetans amb una evident maniobra d'intimidació i assolint el territori sedetà on tingué lloc la batalla. El fet que l'autor singularitzi d'una banda els ausetans i de l'altra els ilergets ens sembla una mesura "geogràfica" per descriure l'abast de la revolta en aquests territoris de l'interior, que acaba amb derrota i una violenta repressió dels indígenes, especialment els ilergets.

L'aixecament del $197 \mathrm{aC}$, en el qual també participen els ausetans, té ja una perspectiva molt diferent respecte de les revoltes anteriors. Es tracta en aquest cas d'un aixecament generalitzat dels territoris ibèrics contra les imposicions romanes, on la dicotomia entre pobles de l'interior i de la costa ja és trencada. Pierre Jacob continua atribuint aquest aixecament als ausetans de l'Ebre, tot i que en aquest cas és més difícil de justificar, atès que els ilergets ja no participen d'aquesta revolta, i en canvi sí els indigets i altres pobles propers del territori ausetà clàssic. Aquesta vegada és ben explícit que la repressió arriba per Empúries, on els exèrcits s'enfronten a una confederació d'ibers revoltats, que acaba en una gran desfeta. Després d'aquesta batalla, les fonts expliquen que Cató va procedir a pacificar el territori on, segons sembla va obligar els indígenes a destruir-se les pròpies fortaleses a canvi de salvar els poblats.

L'arqueologia ausetana, com la de molts altres pobles ibèrics, també sembla mostrar reflexos d'aquesta derrota. Les fortaleses del Turó del Montgròs i del Casol de Puigcastellet queden, en aquest moment, abandonades. Pel que fa a l'Esquerda, en aquesta fase es viu l'enderroc de la muralla i el rebliment de les estructures que hi són associades. La disposició dels potentíssims enderrocs de la fortalesa ibèrica recorden més una demolició organitzada que una destrucció violenta. L'assentament perdrà part de la seva traça urbanística $\mathrm{i}$, tot i que continuarà ocupada durant els segles II i i aC, creiem que haurà perdut la seva funció de lloc central, fins a ser abandonada entorn del canvi d'era (Ollich et al., 1995).

Després d'aquests períodes convulsos, el canvi de paradigma que es produeix en el territori ausetà clàssic també és coherent amb els fets anteriorment esmentats. Els ausetans segueixen essent coneguts per les seves habilitats guerreres, ara com a tropes auxiliars de l'exèrcit romà, com ho demostren, entre d'altres, l'emissió de numerari de plata i de bronze amb la llegenda AUSESKEN, i l'esment d'herois ausetans en el bronze d'Ascoli, formant part de la Turma Salluitana (Molas, 1982). 


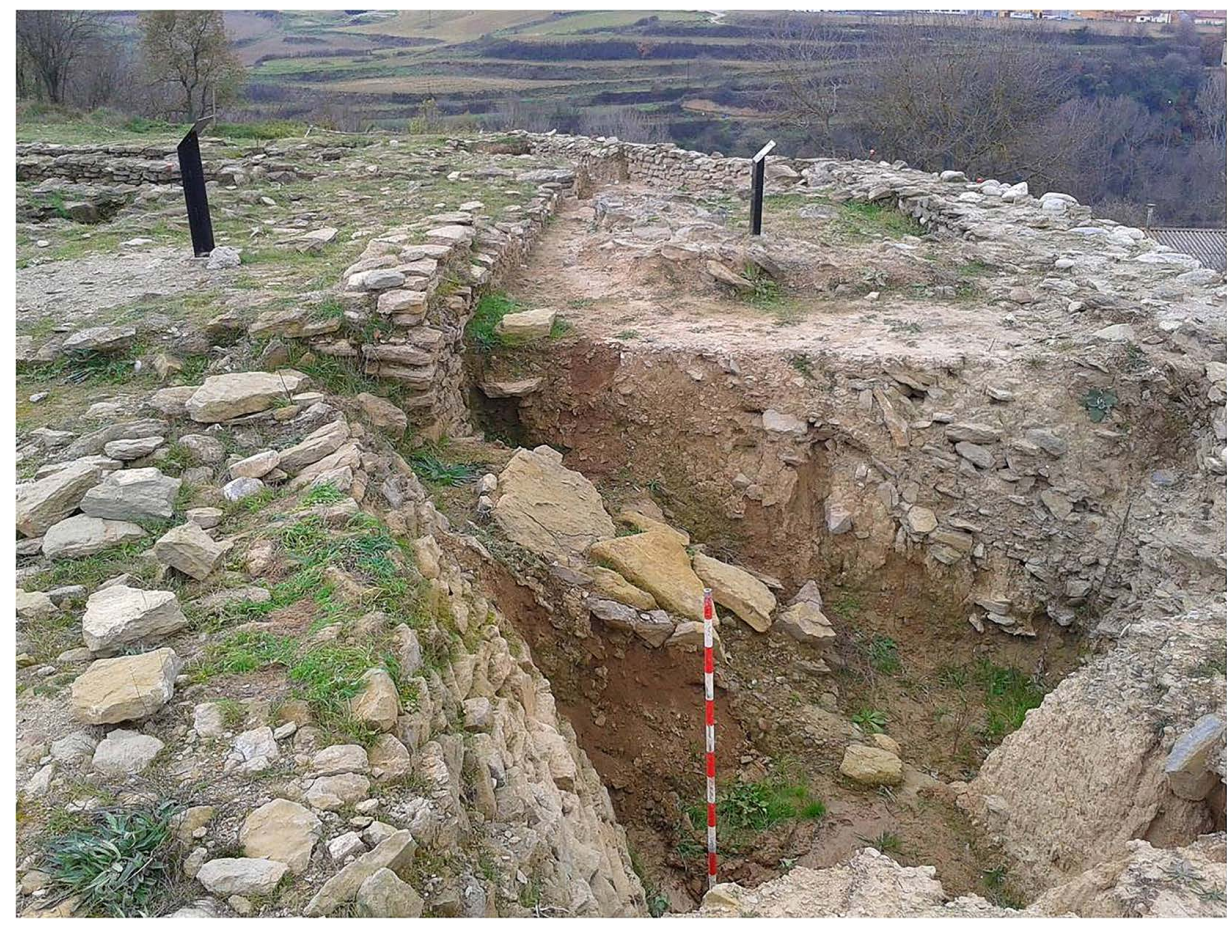

Figura 8. Enderrocs corresponents a la destrucció de la fortalesa de l'Esquerda a inicis del segle II aC.

D'altra banda, l'establiment d'una xarxa viària potent $i$ primerenca al Lluçanès, en un dels territoris intermedis entre els antics territoris ausetà i lacetà, que sembla tenir un evident caràcter militar, sembla que pot ser una mesura de control molt eficient per a uns territoris que, poc temps abans havien protagonitzat violents aixecaments. Tampoc és casual que una de les primeres vies romanes a la Hispania citerior sigui la via de $M a-$ nius Sergius, construïda entorn del 125 $\mathrm{aC}$, i que tingui el caput uiae en territori ausetà, molt abans de la fundació de la ciutat d'Auso (Padrós, 2010).

Per la resta, la pacificació dels territoris suposa l'abandonament dels assenta- ments en altura, la dilució de les antigues fronteres, la intensificació de la romanització, sobretot a partir del focus que suposa el vicus del Camp de les Lloses (Duran et al., 2017), i la proliferació d'assentaments de caràcter agrícola. Tot aquest procés culminarà, ja en època imperial amb la fundació d'una ciutat de nova planta, Auso, a Vic. El nom de la ciutat, heretat dels antics pobladors ibèrics, ens sembla un element final per comprendre la continuïtat dels esdeveniments des del període ibèric ple en aquests territoris del curs mitjà del Ter. 


\section{Conclusió}

L'organització del territori ausetà a mitjans del segle III aC en una estructura de caràcter protoestatal, i l'estudi aprofundit de les seves fortificacions de frontera, demostren que aquest territori es va preparar a fons per als conflictes que es van produir a la fi de la centúria. Aquest registre arqueològic és coherent amb el que refereixen els textos clàssics, i es troben molts més arguments i més sòlids si s'atribueixen al poble ausetà del curs mitjà del Ter, que si cal atribuir-los a un altre poble de nom semblant a la zona de l'Ebre.

Independentment de l'existència o no d'un poble Osità, l'evolució del territori ausetà clàssic, amb una continuïtat des de la fi de la prehistòria fins a la plena romanització, permet explicar de forma molt racional els fets que relaten les fonts a la fi del segle iII inicis del II aC. No oblidem que, si en fem protagonistes aquests Ositans, cal inferir que un poble altament organitzat, que protagonitza uns fets que són significatius per a la historiografia romana que el singularitzen, desapareix poc temps després, sense deixar pràcticament rastre, assimilat per altres pobles.

$\mathrm{Si}$ atribuïm aquests fets als ausetans clàssics, en canvi, només hem d'inferir que Titus Livi va errar el nom del riu Hiberus, nom que, potser, el mateix autor havia ja atribuït en altres ocasions a altres cursos fluvials, com per exemple, el Xúquer (Sureda, 1978), i nom que ja havia portat un altre riu ibèric, el Río Tinto, segons apareix a Aviè i Estrabó (Schulten, 1963). La resta del relat documental és coherent amb el registre arqueològic actual, i estem convençuts que les noves recerques que es produeixin ho acabaran de demostrar.

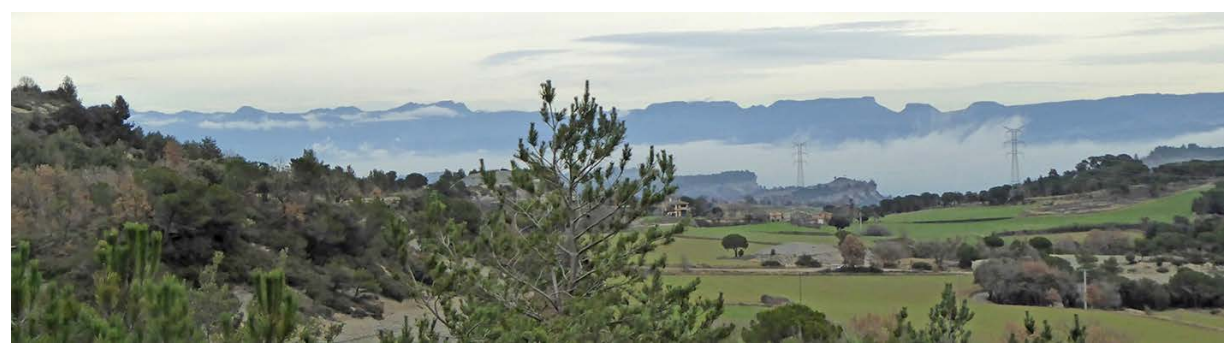

Figura 9. El territori ausetà. Vista general (imatge: C. Jiménez).

\section{Referències i bibliogràfiques}

Beltrán Lloris, F. (1984). «El año 218 aC. Problemas en torno al comienzo de la Segunda Guerra Púnica en la Península Ibèrica». A: PADró, J. (ed.). V Col.loqui internacional d’Arqueologia de Puigcerdà "Hannibal Pyrenaeum transgreditun. Puigcerdà: Institut d'Estudis Ceretans, $147-171$. 

del riu Ter en el conflicte

Benavente, J. A.; Marco, F.; Moret, P. (2003). «El Palao de Alcañiz y el Bajo Aragón durante los siglos II y I aC». Archivo Español de Arqueologia, 76, 231-246.

<https://doi.org/10.3989/aespa.2003.v76.116>

Bosch i Gimpera, P. (1932). Etnologia de la Peninsula ibèrica. Barcelona: Alpha [reed. 2003. Pamplona: Urgoiti].

Burillo, F. (2001). «Propuesta de una territorialidad étnica para el Bajo Aragón. Los Ausetanos del Ebro u Ositanos». Kalathos, 20-21, 159-187.

Busquets, F.; Fàbregas, M.; Corts, A.; Capdevila, N. (2017). «El conjunt monumental del Castell de Besora. Primeres aproximacions a una assentament amb més de dos mil anys d'història». Ausa, 28 (179), 107-126.

Cruz Andreotti, G. (2004). «La construcción de los espacios políticos Ibéricos entre los siglos III y i a.c.: algunas cuestiones metodológicas e históricas a partir de Polibio y Estrabón». Cuadernos de Prehistoria y Arqueología de la Universidad Autónoma de Madrid, 28-29, 35-54. <https://doi.org/10.15366/cupauam2003.29.003>

Duran, M.; Mestres, I.; Padrós, C.; Principal, J. (2016). «Intervencions al jaciment romanorepublicà del Camp de les Lloses (Tona, Osona 2014-1015). Dins del projecte de recerca arqueològica "El NE de la Citerior d'Escipió Emilià a Cèsar: la militarització del paisatge com a model de gestió territorial (NECEEC)"”. A: IV Jornades d'Arqueologia de La Catalunya Central. Barcelona: Departament de Cultura de la Generalitat de Catalunya, 183-191.

Duran, M.; Mestres, I.; Padrós, C.; Principal, J. (2017). «El Camp de les Lloses (Tona, Barcelona): evolución y significado del vicus romanorrepublicano». A: Principal, J.; Naco, T.; Duran, M.; Mestres, I. (eds.). Roma en la península ibèrica presertoriana. Escenarios de implantación militar provincial. Barcelona: Universitat de Barcelona, 153-189.

Groube, L. (1981). «Black Holes in British Prehistory. The analysis of settlement distribution». A: Hodder, I; Isaac, G.; Hammond, N. (eds.). Pattern of the past. Studies in the Honour of David Clarke. Cambridge: Cambridge University Press, 185-211.

Huntingford, E.; Molas, D. (1977). «El jaciment ibero-romà de La Caseta». Ausa, VIII (85), 156-160.

Jасов, P. (1988). «Un doublet dans la géographie livienne de l'Espagne: les Ausetans de l'Ebre». Kalathos, 7-8, 135-147.

Junyent, E. (1976). La Ciutat de Vic i la seva història. Barcelona: Curial.

López, C.; Mullor, A.; Fierro, X.; Galí, D.; Lacuesta, R. (2010). «Les muralles del Montgròs al Brull». Monografies del Montseny, 25, 71-114.

López Mullor, A. (2011). «La muralla principal de l'oppidum ibèric del Montgròs (el Brull) i les seves defenses perifèriques». Revista d'Arqueologia de Ponent, 21, 141-156.

- (2016). El Montgròs, el Brull. Una fortificació ibèrica al Montseny. Guia del Conjunt arqueològic. Barcelona: Diputació de Barcelona.

Maluquer de Motes, J. (1976). «Nuevas inscripciones ibéricas en Catalunya». Pyrenae, 12, 183-189.

Martín, A.; García, J.; Cela, X. (2000). «Nuevas aportaciones sobre la romanización en el territorio de lluro (Hispania Tarraconensis)». Empúries: Revista de Món Clàssic i Antiguitat Tardana, 52, 29-54.

Mestres, J.S. (1998). «Datació per Radiocarboni». A: Rocafiguera, M. et al. (eds.). L'Esquerda 1996-1997. Memòria de les excavacions arqueològiques. Barcelona: Departament de Cultura de la Generalitat de Catalunya.

Molas, M. D. (1974-75). La comarca de Osona. Problemática de su iberización y proceso de romanización a través de su carta arqueológica. Tesi de llicenciatura. Barcelona: Universitat de Barcelona.

— (1976). «Hallazgos en el Casol de Puig Castellet, Folgueroles (Barcelona)». Pyrenae, 12, 177 180. 
- (1982). Els Ausetans i la ciutat d'Ausa. Vic: Patronat d'Estudis Osonencs.

Molas, M.D.; Rocafiguera, M.; Mestres, I. (1988). «La fortalesa ibèrica del Casol de Puigcastellet (1). Una aproximació als límits del territori ausetà». Ausa, 13 (121), 97-131.

Molist, M.; Álvarez, R.; Gómez, A.; Alcántara, R.; Rauret, A. (2016). «Primers resultats de l'estudi de les comunitats agrícoles del riu Ter: cova de les Pixarelles i pla del Castell (Tavertet, Osona). Excavacions 2015-2016». A: Caballé, A. (ed.). IV Jornades d'Arqueologia de la Catalunya Central. Solsona. Barcelona: Departament de Cultura de la Generalitat de Catalunya, 60-167.

Morera, J. (2016). Territori i poblament de Cerdanya a l'Antiguitat. La iberització i romanització de la vall cerdana. Tesi doctoral inèdita. Barcelona: Universitat Autònoma de Barcelona.

Noguera, J.; Ble, E.; Valdés, P. (2013). La Segona Guerra Púnica al nord-est d'Ibèria. Una revisió necessària. Barcelona: Societat Catalana d'Arqueologia.

Nolla, J.M.; Sanmartí, E. (1984). «Algunes consideracions entorn de la romanització del N.E, de Catalunya». A: Vè Col-loqui Internacional d'Arqueologia de Puigcerdà, Hannibal Pyrenaeum Transgreditur. Puigcerdà: Institut d'Estudis Ceretans, 61-132.

Nolla, J.M. (1988). «Gerunda, dels orígens a la fi del món antic». Fonaments, 7, 62-110.

Ollich, I.; Rocafiguera, M. (2002). «L'arqueologia a Osona: 1952-2002». Ausa, 20 (148), 3552.

Ollich, I.; Rocafiguera M.; Amblàs, O.; Pratdesaba, A.; Pujol, A. (2014). «Visigots i carolingis a Osona. Novetats arqueològiques des del jaciment de l'Esquerda». A: III Jornades d'Arqueologia a la Catalunya Central. Roda de Ter: Departament de Cultura de la Generalitat de Catalunya, 14-21.

Ollich, I.; Rocafiguera, M.; Ocaña, M. (2016). "The Southern Carolingian Frontier in Marca Hispanica along the river Ter: Roda Civitas and the Archaeological Site of l'Esquerda (Catalonia)». A: Christie, N.; Herold, H. (ed.). Fortified Settlements in Early Medieval Europe. Oxford: Oxbow Books, 205-217.

Ollich, I.; Rocafiguera, M. (2019). «Antiguas pautas de asentamiento en el yacimiento de l'Esquerda (Osona, Barcelona): un ejemplo de arqueología diacrónica». A: AL-KITAB. Homenaje a Juan Zozaya Stabel-Hansen. Madrid: Asociación Española de Arqueología Medieval (AEAM), 115-160.

PADrós, C. (2009). Estudi del territori a la comarca d'Osona des de l'ibèric ple a l'alt imperi. Treball de final de Màster. Barcelona: Universitat de Barcelona.

- (2010). «El territori de la Plana ausetana i el seu entorn des de l'Ibèric Ple a l'Alt Imperi». Cypsela, 18, 243-262.

- (2011). «Ausetans i Ositans, un estat de la qüestió». Monografies del Montseny, 26, 25-36.

- (2016). «La problemática de las fuentes clásicas. Reflexiones y planteamientos del caso Ausetano». Quaderns de Prehistòria i Arqueologia de Castelló, 34, 221-231.

Padrós, C.; Pujol, À.; SAla, R. (2015). «Puig Ciutat (Oristà, Barcelona): Un praesidium pompeià als peus dels Pirineus?». Revista d'Arqueologia de Ponent, 25, 277-290.

Pratdesaba, A. (2015). El procés de fortificació i reocupació del territori a Catalunya entre els rius Ter i Llobregat en època altmedieval i carolingia: el cas de l'Esquerda, segles VIII-X. Tesi doctoral inèdita. Barcelona: Universitat de Barcelona.

Principal, J.; Pujol, A.; Sala, R. (2018). «El Clascar (Malla): primeres evidències arqueològiques d'ocupació ibèrica». A: III Jornades d'Estudis de la Vall del Ges i Bisaura. Osona al Període Ibèric. Torelló: Associació d'Estudis Torellonencs.

Quesada, F. (2000). «Territorio, etnicidad y cultura material. Estelas del Bajo Aragón en Cataluña Nororiental». Kalathos, 18-19, 95-106.

Revilla, V.; Santacana, J. (2015). Catalunya Romana. Barcelona: Dalmau.

Rocafiguera, M. (1995). Osona ibèrica: el territori dels antics ausetans. Vic: Patronat d'Estudis Osonencs. 

del riu Ter en el conflicte

- (2005). «Arquitectura ibèrica ausetana. Materials i tècniques de construcció al jaciment de l'Esquerda (segle v aC)». Fonaments, 12, 235-250.

- (2019). El territori ausetà: la construcció d'un espai des de l'època ibèrica fins als temps visigòtics. Tesi doctoral inèdita. Barcelona: Universitat de Barcelona.

- (en premsa). «L'Esquerda, ciutat ausetana». A: Actes de la III Jornada d'Estudis de la Vall del Ges i Bisaura. Osona al Periode Ibèric. Torelló: Associació d'Estudis Torellonencs.

Rocafiguera, M.; Ollich, I.; Amblàs, O. (2012). «L'oppidum ibèric de l'Esquerda. Darreres aportacions i noves línies de recerca». A: II Jornades d'Arqueologia a la Catalunya Central. Vic: Departament de Cultura de la Generalitat de Catalunya, 118-124.

Sanmartí, J. (2014). "L'estat del coneixement sobre la Cultura ibérica a Catalunya». Butlletí de la Societat Catalana d'Estudis Històrics, 25, 227-260. <http://doi.org/10.2436/20.1001.01.131>

Sanmartí, J.; Santacana, J. (2005). Els ibers del Nord. Barcelona: Dalmau.

Schulten, A. (1963). Geografía y etnología Antiguas de la Península Ibérica. Madrid: CSIC.

Serrat, D.; Ollich, I.; Rocafiguera, M.; Ocaña, M. (2015). "Condicionants geològics i estructura urbana de la Roda Civitas». A: Vila, J.M. (ed.). V Congrés Acram. Barcelona: ACRAM, 385-390.

Sureda, N. (1978). «El Río Ebro y los íberos en las fuentes antiguas». Ampurias, 38-40, 567 576.

Tarradell, M. (1962). Les Arrels de Catalunya. Barcelona: Edicions 62. 